\title{
OVARIAN STEROID CELL TUMOR: REPORT OF FOUR CASES
}

\author{
Sevgi KOC ${ }^{1}$, Yusuf Aytac TOHMA ${ }^{1}$, Asude OZGUL ${ }^{1}$, Alper KARALOK ${ }^{1}$, Işin UREYEN ${ }^{1}$, Taner TURAN ${ }^{1}$, \\ Dilek BULBUL ${ }^{2}$, Gokhan TULUNAY ${ }^{1}$
}

1 Etlik Zubeyde Hanim Women Health Teaching and Research Hospital, Gynecologic Oncology Clinic, Ankara, Turkey

2 Etlik Zubeyde Hanim Women Health Teaching and Research Hospital, Department of Pathology, Ankara, Turkey

\section{SUMMARY}

Steroid cell tumors are tumors that account for less than $0.1 \%$ of all ovarian malignant tumors and cause increase in secretion of androgen or estrogen. Steroid cell tumors usually occur in the post-menopausal period. This article reports four steroid cell tumor cases who underwent surgery for overian mass during post-menopausal period, who were diagnosed with steroid cell tumor after histopathological examination and displayed different clinical manifestations. No signs of increased hormonal activity in two of these cases were observed. On the other hand, the other two cases applied with complaints of menopausal vaginal bleeding, which led to the consideration of increased estrogenic activity in these two cases.

Key words: ovary, postmenopausal vaginal bleeding, steroid cell tumor

Journal of Turkish Society of Obstetrics and Gynecology, (J Turk Soc Obstet Gynecol), 2013; Vol: 10, Issue: 4, Pages: 267- 71

\section{OVARİAN STEROİD HÜCRELİ TÜMÖR: DÖRT OLGUNUN SUNUMU}

\section{ÖZET}

Steroid hücreli tümörler, ovarian malignitelerin \%0.1'inden azını oluşturan, androjen veya östrojen sekresyon artışına neden olan tümörlerdir. Çoğunlukla postmenopozal dönemde görülmektedir. Bu makalede, postmenopozal dönemde ovarian kitle nedeniyle opere edilen, histopatolojik değerlendirmede steroid hücreli tümör tanısı alan ve farklı klinik tablo ile prezente olan dört ovarian steroid hücreli tümör olgusu sunuldu. İki olguda kliniğe yansımış hormonal aktivite artışı saptanmadı. Diğer iki olgu ise, postmenapozal vajinal kanama yakınmasıyla başvurdu ve bu olgularda östrojenik aktivite artışı düşünüldü.

Anahtar kelimeler: over, postmenapozal vajinal kanama, steroid hücreli tümör

Türk Jinekoloji ve Obstetrik Derneği Dergisi, (J Turk Soc Obstet Gynecol), 2013; Cilt: 10, Sayl: 4, Sayfa: $267-71$

Address for Correspondence: Yusuf Aytaç Tohma. Etlik Zübeyde Hanım Kadın Hastalıkları ve Eğitim ve Araştırma Hastanesi, Jinekoloji Onkoloji Kliniği, Ankara

Phone: + $90(555) 5640315$

e-mail: aytactohma@hotmail.com

Received: 23 October 2012, revised:24 May 2013, accepted: 26 May 2013, online publication: 28 May 2013 


\section{INTRODUCTION}

Steroid cell tumors are rare sex cord stromal tumors and account for less than $0.1 \%$ of all ovarian tumors ${ }^{(1)}$. Previously this tumor was also known as "lipid" or "lipid cell tumor"(2). However, there is either minimal or no lipid in $25 \%$ of these tumors. For this reason, in 1979 Scully used the term "overin steroid cell tumors" for the first time ${ }^{(2)}$. Though steroid cell tumors can be observed at all ages, their incidence increases especially in the 5 th-6th decades $(3,4)$.

Steroid cell tumors are categorized as stromal luteoma, leydig cell tumors (hilar/nonhilar) and steroid cell tumors NOS (not otherwise specified) ${ }^{(5)}$. The most prevalent group of tumors is steroid cell tumors NOS.

In tumors comprised of cells, such as leydig, lutein and adrenal cortical cells, which synthesize steroid hormone, clinical manifestation develops according to hiperandrogenism in most cases ${ }^{(6,7)}$. In $6-23 \%$ of the cases, clinical findings of increased estrogen activity ${ }^{(8)}$ are at the forefront. On the other hand, in $25 \%$ of the cases, there is no hormonal activity ${ }^{(9)}$.

The aim of this study was to present four cases who were diagnosed with steroid cell tumor in our clinic.

\section{Case 1}

The case, who was 77 years of age in her postmenopausal period, applied to our hospital with the complaint of urinary incontinence. The routine laboratory findings of the patient, who had no feature in her history, were within normal limits. No findings of virilization were observed during the physical examination of the patient. During the gynaecological examination, a mass of approximately $6 \mathrm{~cm}$ was detected in the right adnexal area. The transvaginal ultrasonography (TVUSG) revealed an endometrial thickness of $9 \mathrm{~mm}$, and an approximately $72 \mathrm{~mm}$-sized solid-cystic mass, surrounded with free liquid in the right ovary area. The preoperative CA 125 value was $69 \mathrm{IU} / \mathrm{ml}$. Total abdominal hysterectomy, bilateral salpingo-ooforectomy and infracolic omentectomy were performed in the patient who was diagnosed with pelvic mass and underwent the surgery. The intraoperative pathological assessment reported "possibility of a steroid cell tumor". In the paraffin blocks of the right ovary evaluated in 10 high power fields, a steroid cell ovarian tumor with the largest diameter being $8 \mathrm{~cm}$ was reported with grade 2 nuclear atypia, hemorrhage and one or two mitoses (1-2 mitoses/10 HPF). These hystopathological findings indicated that the case had the possibility of being clinically malignant. It was decided that that patient should not receive adjuvant treatment during the postoperative period. The patient did not come to the follow-up examinations after operation.

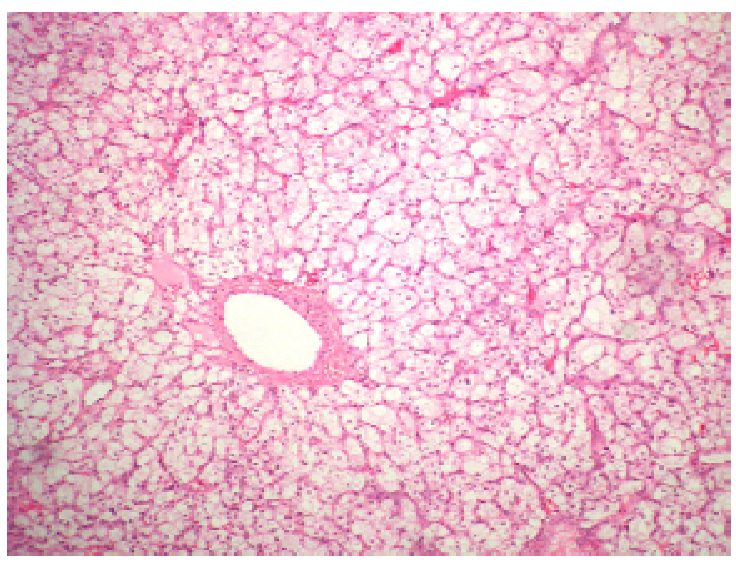

Figure 1: The postoperative paraffin block section of case 1.

\section{Case 2}

In the TVUSG performed during the routine followup examinations at the menopause clinic of the 52 year-old case, who did not have active complaints, a $66 \times 35 \mathrm{~mm}$ mass with the possibility of dermoid cyst was detected in the right ovary. There was no feature in the patient's physical examination, her history and family history. The gynaecological examination, during which an approximately $6 \mathrm{~cm}$ mass was palpated in the right adnexial area, revealed a CA 125 value of $9.07 \mathrm{IU} / \mathrm{ml}$. With the preliminary diagnosis of pelvic mass, laparoscopic right salpingo-ooforectomy was performed. The intraoperative pathological examination reported "malignancy was not observed". The paraffin block indicated a right ovarian steroid cell tumor; the largest diameter of the capsule was $8 \mathrm{~cm}$ and the capsule had a ruptured appearance; there was 1 mitosis /10 HPF, focal light atypia and focal hemorrhage but there was no presence of necrosis. Based on these findings, it was decided that the potential for malignancy was low. Adjuvant treatment during the postoperative period was not considered. The patient did not come to the follow-up examinations after the operation. 


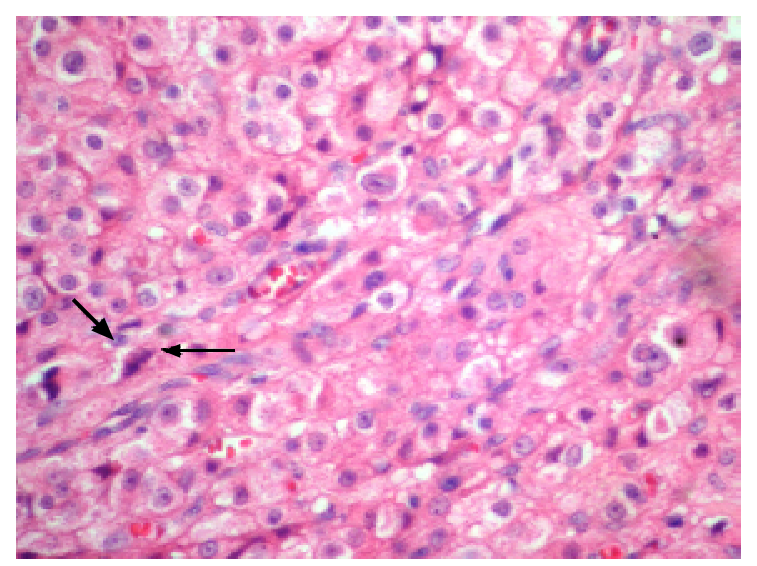

Figure 2: The postoperative paraffin block section of case 1.

\section{Case 3}

The 64-year-old case who was in her postmenopausal period applied to our hospital with vaginal bleeding complaints. The routine laboratory findings of the patient, who had no feature in her history and family history, were within normal limits. In the physical examination of the case, virilization and increased hormonal activity findings were not observed. It was thought that postmenopausal vaginal bleeding could be associated with hyperestrogenic environment. A 10 cm-diameter mobile mass, the borders of which could not be clearly differentiated from the uterus and right ovary and filled up the Douglas space, was detected during the gynaecological examination. The TVUSG revealed a 120 x $60 \mathrm{~mm}$ molticule cystic mass, where there were papillomatosis vegetations of $45 \times 30 \mathrm{~mm}$ and $20 \times 18 \mathrm{~mm}$ diameter in the right ovary area of the paitent whose endometrium thickness was $16 \mathrm{~mm}$. The preoperative CA 125 value was $8.04 \mathrm{IU} / \mathrm{ml}$. After endometrial sampling, complex hyperplasis without atypia was reported. With the preliminary diagnosis of pelvic mass, total abdominal hysteretomy and bilateral salpingo-ooforectomy were performed. During the intraoperative pathology examination, it was decided that the paraffin block should be examined. The paraffin block indicated a steroid cell ovarian tumor with 1012 mitoses/10 HPF and moderate atypia cells, and an immuno-hystochemical study was advised. Simple hyperplastic variations without atypia in the endometrium were reported. In the immunochemical stains made with EMA, inhibin, and calretinin, it was detected that the tissue was stained extensively positive with calretinin and inhibin, and stained negative with EMA. In addition, it was found that in the tumor there was light-moderate degree pleomorphism and focal areas of necrosis with mostly 1-2 mitoses/ 10 HPF but in some points it increased to 6-7 mitoses. Based on these hystopathological findings, the case was thought to have the possibility of being clinically malignant. It was decided that the patient would be followed without adjuvant treatment. No problem was detected in the $60^{\text {th }}$ month of follow up of the patient.

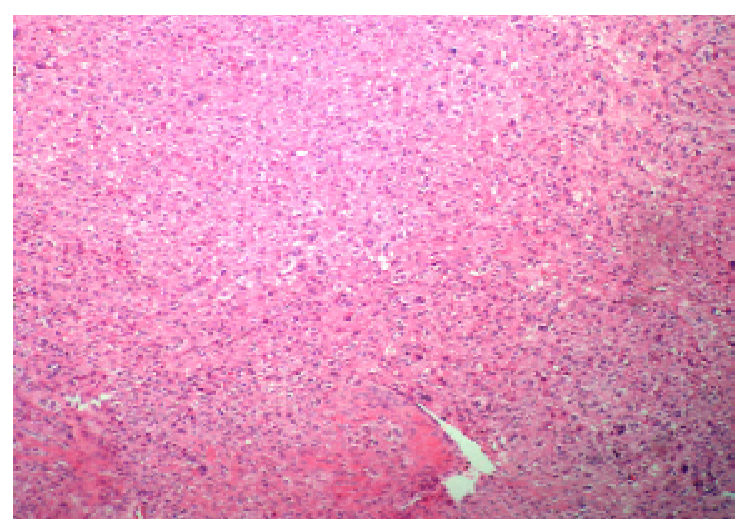

Figure 3: The postoperative paraffin block section of case 1.

\section{Case 4}

The 52-year-old patient, who had been in her postmenopausal period for 5 years, applied to our hospital with postmenopausal bleeding complaints. The routine laboratory findings of the patient, who had no feature in her history and family history, were within normal limits. No virilization finidngs were observed in the patient's physical examination. No pathology was detected in the gynaecological examination. The TVUSG revealed an endometrial thickness of $12 \mathrm{~mm}$ and normal bilateral tubes and ovaries. Endortermial sampling was performed with suspected endometrial hyperplasis. The result was reported as complex hyperplasis with atypia. Based on this diagnosis, total abdominal hysterectomy and bilateral salpingoooforectomy were performed. As a result of postoperative hystopathological examination, simple endometrial hyperplasis without atypia was reported. It was reported that it was in compatibility with material steroid cell tumor of $2 \mathrm{~cm}$ daimeter and with smooth borders in the right ovary. There was clear nuclear atypia and increased mitotic activity. Based on these hystopathological findings, it was thought that the case had the possibility of being clinically malignant. It was decided that the patient be followed without adjuvant treatment. No problem was detected in the $60^{\text {th }}$ month of the follow-up examination of the patient. 


\section{DISCUSSION}

Overian steroid cell tumors are a group of tumours of heterogenous structure made up of cells similar to those that synthesize steroid hormone, such as leydig, lutein and adrenal cortical cells ${ }^{(6)}$. In most of the cases, clinical presentation of steroid cell tumors shows virilation based on hyperandrogenism and hirsutism. Hyperandrogenism is observed in most of the cases ${ }^{(7)}$. In relation to this tumor, virilization findings such as voice deepening, breast atrophy, increase in muscle mass, cliteromegaly, and increase in libido can be detected. $6-23 \%$ of the cases are presented with menorrhagia and postmenopausal bleeding associated with increased estrogenic activity $(4,7,8)$. In addition, cases of Cushing syndrome, congenital adrenal hyperplasis and isosexual pubertas praecox, deriving from hormonal activity, were reported $(10,11)$. Yet, in $25 \%$ of steroid cell tumors, there is no hormonal activity (9). In all four of the cases presented, no clinical finding indicating a different increase of androgenic activity. In the first two cases, no increase in hormonal activity that reflected clinically was considered. The other two cases, however, had applied to our clinic with clinically observant increased hormonal activity. These two cases had postmenopausal bleeding complaints. In the third case, the endometrial thickness was observed to be $16 \mathrm{~mm}$ and the endometrial sampling result was complex hyperplasia without atypia. The postmenopausal bleeding and endometrial hyperplasia in these cases were attributed to increased estrogenic acitivity.

In the pathological assessment of the steroid cells, $>10$ mitoz/10 HPF, presence of necrosis, the diameter of the tumor being $>7 \mathrm{~cm}$, presence of a hemorrhage, and grade 2 and 3 nuclear batypia were interpreted as indicating $92 \%, 86 \%, 78 \%, 77 \%$, and $64 \%$ malignancy, respectively. The hystopathological assessment of the first case was reported as overian tumor in the right ovary with $8 \mathrm{~cm}$-steroid cells with 1-2 mitoses/10 HPF and grade 2 nuclear atypia cells. Based on these findings, the case was was thought to have the possibility of being malignant. During the hystopathological assessment of the second case, it was reported that the tumor was in the right ovary, the capsule's largest diameter was $8 \mathrm{~cm}$ and had a ruptured appearance, there was 1 mitosis /10 HPF, focal light atypia and focal hemmorrage but no presence of necrosis. Based on these findings, it was decided that the malignancy potential of the case was low. The hystopathological assessment of the third and fourth cases were clear nuclear atypia and increased mitotic activity. For this reason, the cases were thought to have the possibility of being malignant. In all the four cases presented, adjuvant treatment was not considered as they did not completely meet the malignancy criteria, and it was decided that they be followed without treatment.

The incidence of steroid cell tumors increases especially in the $5^{\text {th }}$ and 6 th decades ${ }^{(4)}$. Consistent with literature, of the cases presented in this study, the first was 77 years of age, the third was 64 , and the other two were 52 , and all four patients were in their postmenopausal periods.

The first step of treatment in steroid cell tumors is surgery. In the reproductive period, fertility protective surgery should be proposed as an alternative. As the rate of observing these tumors being bilateral is $6 \%$, unilateral salpingo-ooforectomy in these patients would be sufficient ${ }^{(12)}$. Patients who do not have postmenopausal or fertility requirement, staged surgery should be conducted in those who have total abdominal hysterectomy and bilateral salpingo-ooforectomy and malignant criteria.

Approximately $25-43 \%$ of steroid cell tumors are malignant ${ }^{(13,14)}$. In malignant tumors, postoperative adjuvant chemotherapy is required. However, since diagnosis is generally made in the early stages of these ovarian tumors and since reoccurence is not frequent, there is not enough information about the necessity of chemotherapy and radiotherapy and the required therapotic dosis that should be applied.

\section{CONCLUSION}

Steroid cell tumors are ovarian tumors that are rare sex chord stromal tumors which account for $0.1-0.2 \%$ of all ovarian tumors. They are usually benign and unilateral and generally appear during the postmenopausal period with hyperandrogenism findings. In the three of the cases presented, there were no hyperandrogenism findings. However, in one of the cases hyperestrogenism findings were observed. As in our cases, the treatment of steroid cell tumors is generally limited to surgery treatment. 


\section{REFERENCES}

1. Boyraz G, Selcuk I, Yusifli Z, Usubutun A, Gunalp S. Steroid cell tumor of the ovary in an adolescent: A rare case report. Case Rep Med. 2013:2013:527698.

2. Scully RE. Tumors of the ovary and maldeveloped gonads. Atlas of tumor pathology. Second series. Fascicle 16. Armed Forces Institute of Pathology, Washington, 1979 p. 246-62.

3. Young R.H and Shully R.E. Steroid cell tumors of the ovary in Obstetric \& Gynecological Pathology, H. Fox and M. Wells, eds. Churchill Livingstone, Edinburgh, Spain, 2003 p. 84556.

4. Hayes MC, Find all citations by this author (default) Or filter your current search Scully RE. Stromal luteoma of the ovary: a clinicopathological analysis of 25 cases. Int J Gynecol Pathol 1987;6(4):313-21.

5. Young R, Clement PB, Scully RE. Sex cord stromal, steroid cell and germ cell tumours of ovary. In: Mills SE, Carter D, Greenson JK, Reuter VE, Stoler MH Sternberg's Diagnostic Surgical Pathology. Vol. 2 5th edition. Philadelphia: Lippincott Williams and Wilkins; 2009. p. 2592-95.

6. Hayes MC, Find all citations by this author (default) Or filter your current search Scully RE. Ovarian steroid cell tumors (not otherwise specified). A clinicopathological analysis of 63 cases. Am J Surg Pathol 1987 Nov;11(11):835-45.

7. Powell J.L, Dulaney D.P, Shiro B.C. Androgen-secreting steroid cell tumor of the ovary. Southern Medical Journal
2000 Dec;93(12):1201-4.

8. Elhadd TA, Connolly V, Cruickshank D, Kelly WF. An ovarian lipid cell tumour causing virilization and Cushing's syndrome. Clin Endocrinol 1996 Jun;44(6):723- 5.

9. Ulukuş Ç, Koyuncuoğlu M, Özen E, Erten O. Steroid hücreli tümör: Olgu sunumu. Jinekoloji Obstetrik Dergisi 2003; 13(4): 322- 4 .

10. Young RH, Scully RE. Sex cord-stromal, steroid cell and other ovarian tumors with endocrine, paraendocrine and paraneoplastic manifestation. In: Kurman RJ (ed). Blaustein's pathology of the female genital tract, 4th ed. Springer, Berlin Heidelberg New York. 1994 p. 818-24.

11. Baş F, Saka N, Darendeliler F, Tuzlali S, Ilhan R, Bundak R, Günöz H. Bilateral ovarian steroid cell tumor in congenital adrenal hyperplasia due to classic 11 beta-hydroxylase deficiency. J Pediatr Endocrinol Metabol 2000 Jun;13(6):663-7.

12. Kim YT, Kim SW, Yoon BS, Kim SH, Kim JH, Kim JW et al. An ovarian steroid cell tumor causing virilization and massive ascites. Yonsei Med J 2007 Feb 28;48(1):142- 6.

13. Wang PH, Chao HT, Lee RC, Lai CR, Lee WL, Kwok CF et al. Steroid cell tumors of the ovary: clinical, ultrasonic, and MRI diagnosis: a case report. Eur J Radiol 1998 Feb;26(3): 269-73.

14. Duncan T.J, Lee S, Acheson A.G, and Hammond R.H. An ovarian stromal tumor with luteinized cells: an unusual recurrence of an unusual tumor. Int J Gynecol Cancer 2008 Jan-Feb;18(1):172-5. 